\title{
Author manuscript
}

J Am Water Resour Assoc. Author manuscript; available in PMC 2020 July 23.

About author manuscripts

Submit a manuscript

Published in final edited form as:

J Am Water Resour Assoc. 2019 April 5; 55(2): 497-510. doi:10.1111/1752-1688.12731.

\section{Integration of SWAT and HSPF for Simulation of Sediment Sources in Legacy Sediment-Impacted Agricultural Watersheds}

\author{
Hillary N. Yonce, \\ Integrated Water Management, Tetra Tech, Durham, North Carolina, USA
}

Ann Keeley,

National Risk Management Research Laboratory, U.S. Environmental Protection Agency, Ada, Oklahoma, USA

Timothy J. Canfield,

National Risk Management Research Laboratory, U.S. Environmental Protection Agency, Ada, Oklahoma, USA

Jonathan B. Butcher, Integrated Water Management, Tetra Tech, Durham, North Carolina, USA

Michael J. Paul

Integrated Water Management, Tetra Tech, Durham, North Carolina, USA

\section{Abstract}

A total maximum daily load for the Chesapeake Bay requires reduction in pollutant load from sources within the Bay watersheds. The Conestoga River watershed has been identified as a major source of sediment load to the Bay. Upland loads of sediment from agriculture are a concern; however, a large proportion of the sediment load in the Conestoga River has been linked to scour of legacy sediment associated with historic millpond sites. Clarifying this distinction and identifying specific segments associated with upland vs. channel sources has important implications for future management. In order to address this important question, we combined the strengths of two widely accepted watershed management models - Soil and Water Assessment Tool (SWAT) for upland agricultural processes, and Hydrologic Simulation Program FORTRAN (HSPF) for instream fate and transport - to create a novel linked modeling system to predict sediment loading from critical sources in the watershed including upland and channel sources, and to aid in targeted implementation of management practices. The model indicates approximately $66 \%$ of the total sediment load is derived from instream sources, in agreement with other studies in the region and can be used to support identification of these channel source segments vs. upland source segments, further improving targeted management. The innovated linked SWAT-HSPF model implemented in this study is useful for other watersheds where both upland agriculture and instream processes are important sources of sediment load. 


\section{Keywords}

sediment transport; runoff; nonpoint source pollution; simulation

\section{INTRODUCTION}

The Conestoga River, a tributary of the Susquehanna River, drains approximately 475 square miles of primarily Lancaster County in eastern Pennsylvania. Agriculture is the dominant landuse in the watershed with tracts of urban and forested land. Lithology of the watershed is primarily comprised of dolomite, sandstone, and limestone. Karst topography is present in a significant portion of the Conestoga River watershed (Reese and Kochanov 2003), and is largely characterized by surface depressions and a relative lack of actual sinkholes. A total maximum daily load established for the Chesapeake Bay in December 2010 by the United States Environmental Protection Agency (USEPA) requires pollution reductions from major sources of sediment and nutrients, and institutes pollution limits on the Bay watersheds. Susquehanna River is one of the highest contributors of sediment to the Chesapeake Bay, and one of the highest yields in the Susquehanna River is from the Conestoga River (Phillips 2007). Agricultural production combined with milldams constructed from the 17th to the 19th Centuries on the Conestoga River and its tributaries resulted in settling of large quantities of fine sediment in their respective millponds (Walter and Merritts 2008). Walter and Merritts (2008) estimated a very high historic milldam density of 0.14-0.15 dams per $\mathrm{km}^{2}$ in the state of Pennsylvania. The study identified more than 1,000 dams in Lancaster, Chester, and York counties by the mid-19th Century and notes that a large proportion of these dams have breached. Erosion of legacy sediment from such breached millpond sites are major sources of sediment load to the Conestoga River (Walter et al. 2007; Merritts et al. 2010). Schenk and Hupp (2009) reported an average load of approximately 6,200 tons/year from instream sources in the Little Conestoga Creek (a tributary of the Conestoga River). Walter et al. (2007) attribute an average load of 102,000 tons/year to stream sources in the Conestoga River. Based on computational simulations over a 300-year period, significant interannual variability in stream sediment production is reported for the Conestoga River system (Merritts et al. 2010). Walter et al. (2007) suggested that instream sources account for $63 \%$ of the long-term sediment load at the mouth of the Conestoga River. Based on a sediment source analysis using sediment fingerprints, $63 \%$ of total sediment load was attributed to instream sources in the Little Conestoga Creek (Gellis et al. 2009). Carbon, phosphorus, and isotopic stable carbon were used as tracers for sediment samples collected in the study.

Restoration efforts in the watershed have focused on removal of accumulated sediment, and restoring the natural morphology and aquatic ecosystem of the stream network (USEPA 2011). Prioritization of pollutant load reduction efforts in the watershed will greatly benefit from identification of both upland practices and instream former millpond sites that have the highest sediment yields. A watershed modeling system for the Conestoga River watershed was therefore developed to quantify both upland and instream sediment sources and aid in the identification of critical stream segments for legacy sediment erosion sources. 
Based on the studies discussed above, we can assume that upland sources represent a smaller yet significant proportion of the sediment load in the Conestoga River watershed. Upland sediment loads in the watershed are primarily associated with agricultural practices and other land-disturbing activities. To address these sources, we apply the Soil and Water Assessment Tool (SWAT, version 635) (Neitsch et al. 2011). SWAT is a daily time-step basin-scale model designed to simulate the impacts of management on water, sediment, nutrient, and pesticide yield in a watershed. SWAT is a semiempirical model capable of long-term continuous simulations and has been extensively implemented in agricultural watersheds throughout the United States (U.S.) (Gassman et al. 2007; Douglas-Mankin et al. 2010), and also in studies within the Chesapeake Bay watershed (Meng et al. 2010; Sexton et al. 2010; Veith et al. 2010). SWAT was developed for the U.S. Department of Agriculture (USDA), Agricultural Research Service and is widely accepted by producers as a watershed planning and assessment tool. It incorporates a crop growth model and contains built-in functions and libraries to simulate agricultural cropping, tillage, and fertilization practices.

While SWAT is a proven tool for simulating agricultural practices, it does not have a robust representation of stream sediment processes. The mechanisms associated with the transport of cohesive and non-cohesive sediment fractions in stream systems are different (Yang 2006). The empirical and physical methods implemented in SWAT for the erosion, deposition, and transport of sediment in a stream system are universally applied across all sediment fractions. Stream sediment loads generated using this simplistic approach are therefore subject to large uncertainties and SWAT is, therefore, not adequate alone for the Conestoga River system where the channels have been identified as a major source of sediment (Walter et al. 2007; Gellis et al. 2009; Merritts et al. 2010).

Scour and deposition in stream segments are complex and fine-scale processes that are influenced by physical and environmental conditions. Several process-based models exist that address such processes but they are often data and resource intensive. For a watershedscale application, we therefore need a tool that implements a more robust physics-based approach than the semiempirical approach in SWAT but relatively simple to implement in a data-poor environment. The Hydrologic Simulation Program FORTRAN (HSPF) (Bicknell et al. 1997) provides dynamic simulation of water, nutrients, and sediment (including upland and instream sediment processes) at a user-specified level of detail and complexity. HSPF simulates instream cohesive and non-cohesive sediment behavior separately. Transport capacity of the non-cohesive sediment fraction is generally calculated as a power function of streamflow velocity in a channel. Scour is simulated if transport capacity exceeds inflow, while deposition is simulated if transport capacity is less than availability in suspension. For the cohesive sediment fraction, a shear stress-based approach is implemented in HSPF. Scour is simulated when shear stress exceeds the critical shear stress and deposition is simulated when the shear stress is less than the critical shear stress for deposition. For shear stresses between the scour and deposition values, transport of suspended material is simulated with no scour or deposition. The more detailed sediment processes implemented in HSPF makes it a suitable tool for addressing the instream portion of the Conestoga River system. HSPF does not contain an integral plant growth model, nor does it provide a library of agricultural cropping, tillage, and fertilization practices, making it a less attractive tool for assessing upland agricultural sources. 
In response to these strengths and limitations, we developed a linked SWAT-HSPF watershed modeling system for the Conestoga River watershed building on the strengths of both models. Simulation of flow and sediment loads from upland sources were accomplished using SWAT, while routing of flow and simulation of sediment processes in the stream system were completed using the HSPF model. Simulations using the linked SWAT-HSPF model were completed at a daily time-step. Instream scour and deposition processes vary considerably on a sub-daily level. The daily time-step model adopted here is therefore not optimal for detailed scour and deposition analysis of individual millponds. The approach adopted in this study is however useful in predicting net scour at the watershed scale and the relative magnitudes of scour among millpond reaches.

\section{METHODS}

\section{Model Development}

Spatial datasets required for the development of a SWAT model are a digital elevation model (DEM), landuse/landcover, and soils. We developed the SWAT model for the Conestoga River watershed in the ArcSWAT interface version 12.1 (Winchell et al. 2013). SWAT is a semi-lumped model in which unit-area responses are combined to produce a total subwatershed response. The unit-area components are referred to as hydrologic response units (HRUs), which are unique combinations of landuse, soil characteristics, and slope class in a subbasin. We used the Chesapeake Bay Watershed Land Cover Data Series 2001 (U.S. Geological Survey [USGS], http://www.pasda.psu.edu/uci/DataSummary.aspx? dataset $=1332$, Accessed October 2015) to represent landuse in the watershed model (shown in Figure 1). Agriculture and pasture are the dominant landuses in the watershed (approximately 51\%) with tracts of forested and urban lands. Management practices affect flow and pollutant loads generated from agricultural lands, so agricultural land in the SWAT model was further classified into different crop types and rotations. Agricultural land in the model was divided into continuous grain corn (30\%), continuous silage corn (35\%), grain corn-soybean two-year rotation (30\%), and generic row crop agriculture (5\%) based on Cropland Data Layer (USDA, National Agricultural Statistics Service [NASS], https:// nassgeodata.gmu.edu/CropScape/, Accessed October 2015) and the NASS (USDA, NASS, https://quickstats.nass.usda.gov/, Accessed October 2015). Pasture land in the model was simulated as hay. Management practices for agricultural crops and hay were specified based on recommendations of the Pennsylvania State Extension Services (http://extension.psu.edu, Accessed October 2015) and are summarized in Table 1. Soil properties in SWAT were based on the Soil Survey Geographic (SSURGO) Database (USDA, Natural Resources Conservation Service, https://gdg.sc.egov.usda.gov/, Accessed October 2015). SSURGO data for this watershed suggest that approximately $86 \%$ of the watershed area is under moderately well-drained soils (hydrologic soil group B). We used two slope classes, $0 \%-3 \%$ and $>3 \%$, in the SWAT model to represent areas under low and moderate/high slopes, respectively. Approximately 50\% of the agricultural and pasture land in the watershed is under 3\% slope. The SWAT model for the Conestoga River watershed was comprised of 12,194 unique HRUs. 
Delineation of subbasins and reaches was completed using a 10-m resolution DEM (USGS, https://viewer.nationalmap.gov/viewer/, Accessed October 2015). As discussed earlier, legacy deposits of sediment are an important sediment source in the watershed and it was therefore important to be able to delineate millpond segments. A spatial dataset of historic dams was therefore used to refine the delineations. The delineation process resulted in 290 subbasins and reaches. The reach lengths vary from $<1$ mile to more than 4 miles, with a median length of approximately 1 mile.

Meteorological data required for a SWAT model are daily precipitation, maximum and minimum air temperature, solar radiation, relative humidity, wind speed, and potential evapotranspiration (PET). In recent years, several gridded meteorological products have been made publicly available that incorporate point and radar estimates of rainfall, do not have data gaps, and have generally undergone extensive quality checks. The PRISM Climate Group (Oregon State University, http://prism.oregonstate.edu, Accessed October 2015) produces daily precipitation, and maximum and minimum temperature grids at an approximate spatial resolution of $4 \times 4 \mathrm{~km}$ for the continental U.S. from 1981 onwards. Recent studies have reported better SWAT model performance using PRISM data compared to other meteorological products (Gao et al. 2017; Radcliffe and Mukundan 2017). Gao et al. (2017) specifically noted that SWAT represented variations in daily streamflow with greater accuracy using PRISM compared to land-based National Climactic Data Center weather stations and Next-Generation Radar (NEXRAD). We therefore used PRISM data spatially aggregated to SWAT model subbasins using an area-weighting approach for precipitation and temperature forcings. The National Land Data Assimilation System (NLDAS2: Land Data Assimilation Systems, National Space and Aeronautics Agency, http:// ldas.gsfc.nasa.gov/nldas/NLDAS2forcing.php, Accessed October 2015) produces gridded precipitation, air temperature, wind speed, longwave and shortwave radiation, specific humidity, air pressure, and PET at an approximate spatial resolution of $12 \times 12 \mathrm{~km}$ for the continental U.S. from 1979 onwards. We used NLDAS2 data temporally aggregated to a daily time-step and then spatially assigned to the SWAT model subbasins using a Thiessen polygon approach to represent solar radiation, wind speed, and relative humidity (calculated using air pressure, specific humidity, and air temperature) forcings in the SWAT model. We chose to use PRISM over NLDAS2 for precipitation on account of its finer spatial resolution. The SWAT model's internal energy balance algorithm based on the PenmanMonteith method (Jensen et al. 1990) was used to generate time series of PET for the simulations.

A typical HSPF model consists of an upland simulation, using an approach similar to the HRU definition in SWAT, linked to stream segments (or RCHRES). The HSPF model for this study was developed with a focus on representation of instream sediment processes and thus consisted only of RCHRES units. For a given RCHRES, the daily flow and sediment load simulated by the SWAT model for the respective subbasins were input to the HSPF model as point source loads at the head of the reach. This approach is adequate because HSPF simulates RCHRES as one-dimensional completely mixed reactors.

Length and change in elevation between the most upstream and downstream ends, for each RCHRES unit in the HSPF model were assigned using delineation generated by the 
ArcSWAT interface. HSPF is a hydrologic model that conserves mass, but not an explicit hydraulic model that conserves momentum. Hydraulic response in HSPF is represented through externally specified piecewise linear function tables of stage-area-storagedischarge relationships ("Functional Tables" or FTABLES) for each model reach. Each row of an FTABLE consists of values of surface area (SA), volume $(V)$, and flow rate for a specified depth of water. FTABLES were developed using the methodology outlined in BASINS Technical Note 2 (USEPA 2007). Trapezoidal geometry was assumed for channel and floodplain, and outflow rate for a given depth of water was calculated using Manning's equation. The parameters required for the development of the FTABLES and the sources used are summarized in Table 2. Mean flow depth $\left(Y_{\mathrm{m}}\right)$ and mean flow width $\left(W_{\mathrm{m}}\right)$ required for FTABLE development were based on regional regression equations developed by Bieger et al. (2015) for streams in the Appalachian Highlands.

$$
\begin{gathered}
Y_{\mathrm{m}}=0.26 \times(\text { Drainage Area })^{0.287} \\
W_{\mathrm{m}}=3.12 \times(\text { Drainage Area })^{0.415}
\end{gathered}
$$

For a given depth of water $(y)$, a channel, SA, $V$, and flow rate were determined using the following equations.

$$
\begin{gathered}
\text { Surface Area }(\mathrm{SA})=L\left(b+2 \times m_{\mathrm{c}} \times y\right) \\
\text { Volume }(V)=L\left(b \times y+m_{c} \times y^{2}\right) \\
\text { Outflow }(Q)=\frac{c}{n}\left(b \times y+m_{\mathrm{c}} \times y^{2}\right)^{5 / 3} \times\left(b+2 \times y \sqrt{m_{\mathrm{c}}^{2}+1}\right)^{-2 / 3} S^{1 / 2} \\
b=W_{\mathrm{m}}-2 \times m_{\mathrm{c}} \times Y_{\mathrm{m}} .
\end{gathered}
$$

Scour and deposition of fine sediment are sensitive to channel dimensions and therefore the use of regional regression equations for FTABLE generation is suboptimal for this study. Channel cross-sectional data are, however, not readily available for most of the Conestoga River system and development of FTABLES from such information is a resource intensive exercise. Our results, therefore, cannot estimate scour and deposition accurately for a particular millpond site, but do provide information on the relative magnitude of scour expected from millpond sites in the watershed. In addition, the linked model also provides estimates of sediment loading from agricultural and urban land, and the relative importance of these sources with respect to the instream component.

\section{Model Linkage}

We developed a Python automation script to simulate the linked SWAT-HSPF modeling system. The sequence of operations accomplished by the script is as follows. 
1. Run the SWAT model.

2. Read SWAT daily flow and sediment time series from the SWAT subbasin level output file (output.sub).

3. Add point source load time series (if any) to SWAT subbasin level flow and sediment yield. Point source discharges in the watershed were input as monthly average time series using data retrieved from the Chesapeake Bay Program (Bay Program Nutrient Point Source Database, https://www.chesapeakebay.net/what/ downloads/bay_program_nutrient_point_source_database, Accessed October 2015).

4. Write subbasin level flow and sediment yield (with point source load added) to two watershed data management (WDM) files, one for water yield and another for sediment yield. Data in the WDM files are input to HSPF via the EXT SOURCES block.

5. Run the HSPF model.

6. Output results.

\section{Calibration and Validation}

We ran the SWAT model from 1985 to 2014, with the first five years of simulation as model warm-up. The HSPF model was run from 1990 to 2014 using SWAT model subbasin level flow and sediment outputs. We first calibrated the linked SWAT-HSPF model for hydrology and subsequently for suspended sediment. Water years 2005-2014 were used as the calibration period. The model was validated against observed streamflow and suspended sediment for water years 1994-2004. While observed streamflow data are available at multiple locations within the watershed, long-term continuous data are only available near the outlet of the watershed - USGS gages at Lancaster and Conestoga. Long-term suspended sediment samples for the watershed were only available at the USGS gage at Conestoga (01576754), which served as the focus of our calibration and validation exercise.

Calibration for hydrology was geared toward a reasonable representation of the hydrologic cycle, including evapotranspiration, snow storage/melt, and streamflow. Simulated monthly evapotranspiration was compared against MODIS Global Evapotranspiration Project (MOD16) estimates of terrestrial evapotranspiration (University of Montana, Numerical Terradynamic Simulation Group, http://www.ntsg.umt.edu/project/modis/mod16.php, Accessed October 2015). The MOD16 global terrestrial evapotranspiration dataset is generated using the algorithms of Mu et al. (2011), and are available at a monthly and eightday time-step since 2000. Simulated evapotranspiration was most sensitive to the soil evaporation compensation factor (ESCO). Calibration for evapotranspiration consisted of adjusting the value of ESCO until a good match was achieved between simulated and MOD16 monthly evapotranspiration.

Simulated streamflow was graphically and statistically compared against observed time series at the USGS streamflow gage 01576754 on the Conestoga River at Conestoga (USGS, National Water Information System, https://waterdata.usgs.gov/nwis/uv?site_no=01576754, 
Accessed October 2015). Calibration for streamflow consisted of a systematic adjustment of parameters aimed at minimizing volumetric errors on total, low, high, storm, and seasonal flows, and constraining them to ranges developed and implemented in previous studies (Lumb et al. 1994; Duda et al. 2012). Performance of the model for daily streamflow was also evaluated using the Nash-Sutcliffe efficiency (NSE) (Nash and Sutcliffe 1970). Performance targets expressed in terms of error statistics, coefficient of determination $\left(\mathrm{R}^{2}\right)$, and NSE are summarized in Table 3.

High flow and stormflow volumes were highly sensitive to SURLAG (refer to Table 4 for parameter definitions and calibrated values). Low flow volumes were sensitive to GWQMN and REVAPMN, while the shape of the hydrograph during low flows was influenced by GW_DELAY and ALPHA_BF. GW_DELAY was generally used as a calibration parameter for the baseflow response of the model. In karst regions, where water enters the aquifer as diffuse infiltration, baseflow can take months to emerge from springs. In karst regions where water enters the aquifer through conduits (sinkholes and sinking streams), baseflow takes shorter periods of time to emerge from springs and it is considered to be more rapid (Echegaray 2009). Since there is not a compelling evidence of matrix-flow (supported by the relative lack of actual sinkholes), it is very likely that the watershed is diffuse infiltration dominated. Since SWAT does not have a parameter to delay the transport of water from the groundwater store to the streamflow, a higher value of GW_DELAY was used for areas affected by karst topography. The values of SFTMP, SMTMP, SMFMX, and SMFMN were modified to improve the match between the simulated and observed hydrographs during the winter and spring snowmelt months. $\mathrm{CH} \_\mathrm{N} 1$ and $\mathrm{CH} \_\mathrm{N} 2$ were parameterized to match the shapes of the simulated and observed hydrographs. Using SWAT 2005 in the James River watershed, Baffaut and Benson (2009) represented sinkholes using ponds with small SAs and large hydraulic conductivities, and losing streams as tributary channels with high streambed hydraulic conductivity. Karst features in the Conestoga River watershed are largely surface depressions with a relative absence of actual sinkholes. Consistent with the study of Baffaut and Benson (2009), we parameterized areas under karst with a nonzero value of $\mathrm{CH}$ _K1 scaled across the modeled subbasins based on the density of karst features.

Calibration for sediment consisted of adjusting parameters in the SWAT and HSPF models to adjust loading from upland sources and stream sources, respectively. SWAT uses the Modified Universal Soil Loss Equation (MUSLE) to simulate sediment loss at the HRU level. The Universal Soil Loss Equation (USLE) is an empirical equation to predict gross erosion and is generally used along with a sediment delivery ratio (DF) to predict sediment yield. DF or sediment DF is defined as the ratio of sediment yield and gross erosion.

MUSLE is a modified version of the USLE that replaces the rainfall energy factor in USLE with a runoff factor and is designed to eliminate the need for a DF. The general form of the runoff factor $(R)$ in the MUSLE equation is shown below,

$$
R=a\left(Q \cdot q_{p}\right)^{b}
$$

where $Q$ is the runoff volume, $q_{\mathrm{p}}$ is the peak runoff rate, and $a$ and $b$ are location coefficients. 
The SWAT model uses 11.8 and 0.56 for the location coefficients $a$ and $b$, respectively. Since estimates of DF are rarely available, it is often difficult to determine the values of the location coefficients in MUSLE, and therefore most SWAT applications have left these coefficients unchanged. Sadeghi et al. (2014) reported a range of location coefficients adopted in prior studies where the location coefficients have been modified based on observed sediment yield. Sediment yield data are rarely available, but attempts have been made in the Chesapeake Bay watershed to estimate sediment yield. The Phase 5 Chesapeake Bay Watershed Model (ftp://ftp.chesapeakebay.net/modeling/P5Documentation/SECTION \%209.pdf) estimates an approximate median DF of 0.25 with a range of 0.10-0.45 (25th75th percentile) for the Piedmont region. The Conestoga River watershed is in the Northern Piedmont region of the Chesapeake Bay watershed.

In the Conestoga River watershed, several studies have attempted to quantify sources of sediment based on analytical and sediment fingerprinting studies. The studies of Gellis et al. (2009), Merritts et al. (2010), and Walter et al. (2007) attribute more than $60 \%$ of the sediment load to channel sources in the Conestoga River waterhshed. The sediment fingerprint study of Gellis et al. (2009) using Cesium-137 attribute a delivery fraction of only $10 \%$ to cropland sources (including deposition of sediment on slopes and instream corridors) to the mouth of the Little Conestoga Creek.

Based on the above studies, we revised the location coefficient $a$ in MUSLE to 0.6 from its default value of 11.8. The coefficient $b$ was left unchanged at 0.56 . The value of the location coefficient $a$ adopted in this study lies well within the range reported by Sadeghi et al. (2014) in their review of MUSLE applications worldwide.

Since SWAT reports sediment load using both MUSLE and USLE, we estimated DF or sediment DF at the subbasin level as the ratio of annual average sediment loads predicted by SWAT using MUSLE and USLE. The median DF is 0.42 with a range of $0.34-0.50$ (25th75th percentile) and are comparable to the DF estimates of the Phase 5 Chesapeake Bay watershed model for the Piedmont region.

Transport of sand (non-cohesive fraction) in HSPF is generally calculated every model timestep for each reach as a power function of average velocity (transport capacity). Based on the inflow and bed storage of sand compared to the transport capacity, sand scour occurs if there is excess capacity. Deposition occurs if sand in suspension in a reach exceeds the transport capacity.

Scour, deposition, and transport of the cohesive fraction (silt and clay) in HSPF is based on user-defined critical shear stresses for silt and clay. Critical shear stresses for deposition and scour are generally determined for each reach based on the examination of simulated shear stresses against streamflow. HSPF simulates scour at a user-defined erodibility rate when the shear stress at a time-step exceeds the critical shear stress for scour. Deposition is simulated when the shear stress is less than the critical shear stress for deposition at a user-defined settling rate. For shear stresses greater than the critical level for deposition but less than the critical value for scour, suspended material in inflow to a reach is transported with no deposition or scour. 
The watershed model was parametrized for instream sediment simulation consistent with the methodology in BASINS Technical Note 8 (USEPA 2006). Critical shear stresses for scour and deposition of silt and clay were determined based on the distribution of simulated shear stress against streamflow on a reach by reach basis. Silt was generally set to deposit below the 20th percentile and scour above the 90th percentile shear stress, while clay was set to deposit below 15th percentile and scour above 85 th percentile. The distribution of simulated shear stress against streamflow for a reach near the mouth of the Conestoga River is shown in Figure 2. Accuracy of FTABLES for modeled stream segments are a critical factor in the accuracy of calculation of shear forces and therefore scour and deposition. FTABLES developed for this study are developed from regional regression equations and likely suffer from inaccuracies in hydraulic characteristics. The percentile-based approach discussed above is used to adjust for these uncertainties in hydraulic characteristics to ensure that the model simulated scour for high flows, deposition for low flows, and transport for moderate flows. Scour and deposition analysis was performed on a reach by reach basis to ensure reasonable instream sediment loss or accumulation behavior. Magnitude of scour of silt and clay was adjusted using the erodibility coefficient $(M)$. Scour and deposition of sand were adjusted using the coefficient (KSAND) and exponent (EXPSAND) in the sandload power function formula (Table 5).

Simulated sediment load was compared against monthly regression loads at the USGS gage on the Conestoga River near Conestoga. Stratified linear regression models of paired sediment load and streamflow on a log-log scale were implemented in the U.S. Army Corps of Engineers load estimation program FLUX32 to generate sediment load time series (see Supporting Information for regression model details). Performance of the model for monthly suspended sediment load was evaluated using criteria recommended by Moriasi et al. (2007). Simulated suspended sediment concentrations were compared to observed using criteria suggested by Duda et al. (2012). Performance targets, based on these studies and used for the evaluation of our model's suspended evaluation, are summarized in Table 6 . Duda et al. (2012) also suggested that the error ranges should be applied to mean concentration values and that larger differences may be expected for individual observations.

\section{RESULTS AND DISCUSSION}

Simulated monthly evapotranspiration compared well with the MOD16 estimates for the Conestoga River watershed (Figure 3). The monthly NSE and the magnitude of error for the simulation period were $0.92 \%$ and $4 \%$, respectively. The ratio of simulated evapotranspiration to precipitation was 0.53 , in the range of $0.50-0.59$ reported for this region in figure 13 of Sanford and Selnick (2013).

The error in daily flow for the calibration and validation periods was $8 \%$ and $1.3 \%$, respectively. The NSEs for daily flow for the calibration and validation periods were 0.83 and 0.72 , respectively. The $R^{2}$ values at 0.83 and 0.74 for the calibration and validation periods, respectively, were similar to the NSE values. The model underestimated some of the highest peak flow events during the validation period resulting in lower values of $R^{2}$ and NSE. The underrepresentation of peaks were generally linked to insufficient precipitation amounts and allude to likely discrepancies in the PRISM dataset. Scatter plots of daily 
simulated against observed streamflow at the USGS gage at Conestoga show good agreement (Figure 4). Based on criteria suggested by Moriasi et al. (2007), the performance of the model for monthly streamflow was rated very good for the calibration and validation periods (summarized in Table 7). Based on the results of the graphical and statistical comparison of evapotranspiration and streamflow, we conclude that the performance of the model for hydrology is good to very good.

The monthly scatterplot of simulated and regression sediment loads exhibits good agreement (Figure 5). Error in mean monthly sediment loads for the calibration and validation periods were $3.1 \%$ and $21.0 \%$, respectively. The NSEs based on monthly simulated and regression loads were 0.83 and 0.68 for the calibration and validation periods, respectively. The $R^{2}$ values at 0.85 and 0.74 for the calibration and validation periods, respectively, were slightly higher than the NSE values. The model generally simulated the trends in observed concentrations well but was unable to simulate some extremely high concentrations (Figure 6). A closer examination of the observed data shows that some of the highest concentrations are not supported by extreme storm events and are likely from bank slumping events. Bank slumping events are complicated processes and are beyond the scope of the HSPF model. The average relative concentration errors for the calibration and validation periods were $65 \%$ and $-9 \%$, respectively. Averages are often inflated by the presence of outliers and in such cases, medians may be a better predictor of the model performance (Moriasi et al. 2007). The median relative concentration errors for the calibration and validation periods were $24 \%$ and 3\%, respectively. Based on the results of the graphical and statistical analysis of load and concentration data, we rate the suspended sediment performance of the model between good and very good.

The model simulated a total instream scour of approximately 103,000 tons/year over the simulation time period. Bulk of the simulated instream scour (approximately 95\%) is associated with millpond reaches. The simulated net instream scour (difference between total scour and deposition) was approximately 86,000 tons/year. This equates to channel sources representing approximately $66 \%$ of the simulated total suspended sediment load near the mouth of the Conestoga River watershed, in agreement with estimates of Walter et al. (2007). Agriculture is the second largest source of sediment in the watershed (27\%) followed by urban land (6\%). For the Little Conestoga Creek (a tributary of the Conestoga River), the model simulates approximately $60 \%$ of the sediment load from stream sources, again generally in agreement with the study of Gellis et al. (2009). The net scour on a reach by reach basis (Figure 7) is variable with bulk of the scour simulated from millpond reaches (Figure 8 ). There is also considerable variability in the proportion of sediment load simulated from instream sources across the modeled subbasins. For subbasins without millponds, this proportion is much lower (average of $2 \%$ ) compared to those with millponds (average of 64\%). Moreover, the bulk of the scoured sediment simulated by the model is comprised of the fine fraction, consistent with erosion of legacy depositional sediment from millponds. 


\section{CONCLUSIONS}

The linked SWAT-HSPF approach adopted for this watershed is readily applicable to other agricultural watersheds where upland and stream components are equally important sources of sediment. Using a linked modeling approach like this overcomes the known lack of explicit routines for agricultural practices in HSPF which are overcome by the SWAT model, while the known limitation of the SWAT model to simulate instream sediment processes is overcome by using HSPF. The modeling results confirm that stream sources in the Conestoga River system represent a large proportion of the total sediment load, and that a large fraction of the instream load is attributable to historic millponds in the watershed. Moreover, the results indicate the relative rank of instream segment sediment scour, which could better inform watershed interventions.

As noted earlier, instream sediment simulation is sensitive to the hydraulic properties which are strongly influenced by the channel geometry. Due to a general paucity of channel geometry data, our study relied on using assumed double trapezoidal cross-sections sized based on estimates of bankfull depth and width generated from regression equations. Future work should consider the use of actual cross-sectional data to minimize uncertainties in sediment transport arising from inaccuracies in channel hydraulic properties.

Instream scour and deposition processes vary considerably on a sub-daily level. The daily time-step adopted for this study is therefore not optimal. It is however important to note water quality outputs from the SWAT model are available only at a daily time-step. Future work should explore ways to resolve the issue of disaggregating daily loads to sub-daily levels for instream simulation at finer time-steps. Statistical disaggregation techniques like the random multiplicative cascade method (Menabde et al. 1997; Molnar and Burlando 2005) may be explored to resolve the issue of using outputs at daily time-step to run simulations at hourly or sub-hourly time-steps.

\section{Supplementary Material}

Refer to Web version on PubMed Central for supplementary material.

\section{ACKNOWLEDGMENTS}

Funding for this work was provided by the U.S. Environmental Protection Agency, Office of Research and Development. Authors S. Sarkar, H.N. Yonce, J.B. Butcher, and M.J. Paul were supported via Work Assignments 1-17 through 4-17 under Contract EP-C-12-060 awarded to Tetra Tech. Authors T.J. Canfield and A. Keeley are employees of the USEPA Office of Research and Development. The views expressed in this manuscript are solely of the authors and do not necessarily reflect the views or policies of the USEPA.

Funding Information

- National Center for Environmental Assessment. Grant Number: EP-C-12-060

- U.S. Environmental Protection Agency, Office of Research and Development 


\section{Literature Cited}

Baffaut C, and Benson VW.2009 "Modeling Flow and Pollutant Transport in a Karst Watershed With SWAT." Transactions of the American Society of Agricultural and Biological Engineers 52 (2): 469-79.

Bicknell BR, Imhoff JC, Kittle JL, Donigian ASJ, and Johanson RC. 1997 "Hydrological Simulation Program-Fortran, User's Manual for Version 11.” Athens, GA: U.S. Environmental Protection Agency, National Exposure Research Laboratory EPA/600/R-97/080, 755 pp.

Bieger K, Rathjens H, Allen PM, and Arnold JG. 2015 "Development and Evaluation of Bankfull Hydraulic Geometry Relationships for the Physiographic Regions of the United States." Journal of the American Water Resources Association 51(3):842-58.

Douglas-Mankin KR, Srinivasan R, and Arnold JG. 2010 "Soil and Water Assessment Tool (SWAT) Model: Current Developments and Applications." Transactions of the American Society of Agricultural and Biological Engineers 53 (5): 1423-31.

Duda PB,Hummel PR,Donigian ASJ, and Imhoff JC. 2012 "BASINS/HSPF: Model Use, Calibration, and Validation." Transactions of the American Society of Agricultural and Biological Engineers 55 (4):1523-47.

Echegaray GAY 2009 "Modification of the SWAT Model to Simulate Hydrologic Processes in a KarstInfluenced Watershed.” Virginia Polytechnic Institute and State University. https:// vtechworks.lib.vt.edu/bitstream/handle/10919/34807/Yactayo_GA_T_2009.pdf? sequence $=1 \&$ isAllowed $=\mathrm{y}$.

Gao J, Sheshukov AY, Yen H, and White MJ. 2017 "Impacts of Alternative Climate Information on Hydrologic Processes with SWAT: A Comparison of NCDC, PRISM and NEXRAD Datasets." Catena 156: 353-64.

Gassman P, Reyes M, Green C, and Arnold J. 2007 "The Soil and Water Assessment Tool: Historical Development, Applications, and Future Research Directions." Transactions of the American Society of Agricultural Engineers 50 (4):1211-50.

Gellis AC, Hupp C, Pavich M, Landwehr J, Banks WSL, Hubbard B, Langland M, Ritchie J, and Reuter J. 2009 "Sources, Transport, and Storage of Sediment at Selected Sites in the Chesapeake Bay Watershed." USGS Scientific Investigations Report 2008-5186, 95 pp.

Jensen ME, Burman RD, and Allen RG. 1990 "Evapotranspiration and Irrigation Water Requirements." ASCE Manuals and Reports on Engineering Practice No. 70, 332 pp.

Lumb AM, McCammon RB, and Kittle JL Jr. 1994 "Users Manual for an Expert System (HSPEXP) for Calibration of the Hydrological Simulation Program-FORTRAN." USGS Water-Resources Investigations Report 94-4168, 107 pp.

Menabde M, Harris D, Seed A, Austin G, and Stow D. 1997 "Multiscaling Properties of Rainfall and Bounded Random Cascades." Water Resources Research 33 (12): 2823-30.

Meng H, Sexton AM, Maddox MC, Sood A, Brown CW, Ferraro RR, and Murtugudde R. 2010 "Modeling Rappahannock River Basin Using SWAT — Pilot for Chesapeake Bay Watershed." Applied Engineering in Agriculture 26 (5): 795-805.

Merritts D, Walter R, and Rahnis M. 2010 "Sediment and Nutrient Loads from Stream Corridor Erosion along Breached Millponds.” Pennsylvania Department of Environmental Protection, Growing Greener Grant, 145 pp.

Molnar P, and Burlando P. 2005 "Preservation of Rainfall Properties in Stochastic Disaggregation by a Simple Random Cascade Model." Atmospheric Research 77: 137-51.

Moriasi DN, Arnold JG, Van Liew MW, Binger RL, Harmel RD, and Veith TL. 2007 "Model Evaluation Guidelines for Systematic Quantification of Accuracy in Watershed Simulations." Transactions of the American Society of Agricultural and Biological Engineers 50 (3): 885-900.

Mu Q, Zhao M, and Running SW. 2011 "Improvements to a MODIS Global Terrestrial Evapotranspiration Algorithm.” Remote Sensing of Environment 115 (8): 1781-800.

Nash JE, and Sutcliffe JV. 1970 "River Flow Forecasting through Conceptual Models Part I — A Discussion of Principles.” Journal of Hydrology 10 (3): 282-90.

Neitsch S, Arnold J, Kiniry J, and Williams J. 2011 "Soil \& Water Assessment Tool Theoretical Documentation Version 2009.” Texas Water Resources Institute, TR-406, 647 pp. 
Phillips SW, ed. 2007 "Synthesis of U.S. Geological Survey Science for the Chesapeake Bay Ecosystem and Implications for Environmental Management." U.S. Geological Survey Circular 1316, $63 \mathrm{pp}$.

Radcliffe DE, and Mukundan R. 2017 "PRISM vs. CFSR Precipitation Data Effects on Calibration and Validation of SWAT Models." Journal of the American Water Resources Association 53(1): 89100.

Reese BSO, and Kochanov WE. 2003 "Digital Karst Density Layer and Compilation of Mapped Karst Features in Pennsylvania.” U.S. Geological Survey Open-File Report 03-471: Digital MappingTechniques 03 - Workshop Proceedings, 17-21.

Sadeghi SHR, Gholami L, Darvishan AK, and Saeidi P. 2014 "A Review of the Application of the MUSLE Model Worldwide.” Hydrological Sciences Journal 59 (2): 365-75.

Sanford WE, and Selnick DL. 2013 "Estimation of Evapotranspiration across the Conterminous United States Using a Regression with Climate and Land-Cover Data." Journal of the American Water Resources Association 49 (1): 217-30.

Schenk ER, and Hupp CR. 2009 "Legacy Effects of Colonial Millponds on Floodplain Sedimentation, Bank Erosion, and Channel Morphology, MID-Atlantic, USA.” Journal of the American Water Resources Association 45 (3): 597-606.

Sexton AM, Sadeghi AM, Zhang X, Srinivasan R, and Shirmohammadi A. 2010 "Using Nexrad and Rain Gauge Precipitation Data for Hydrologic Calibration of SWAT in a Northeastern Watershed." ASABE 53 (5): 1501-10.

USEPA. 2006 BASINS Technical Note 8: Sediment Parameter and Calibration Guidance for HSPF. Washington, D.C: U.S. Environmental Protection Agency, Office of Water.

USEPA. 2007 BASINS Technical Note 2: Two Automated Methods for Creating Hydraulic Function Tables (FTABLES). Washington, D.C: U.S. Environmental Protection Agency, Office of Water.

USEPA. 2011 Aquatic Ecosystem Restoration Efforts Manage Sediment and Improve Ecosystem Services and Functions in the Big Spring Run Watershed. Washington, D.C: U.S. Environmental Protection Agency, Office of Water, EPA 841-F-15-001JJJ, 2 pp.

Veith TL, Van Liew MW, Bosch DD, and Arnold JG. 2010 "Parameter Sensitivity and Uncertainty in SWAT: A Comparison across Five USDA-ARS Watersheds." Transactions of the American Society of Agricultural and Biological Engineers 53 (5): 1477-86.

Walter R, Merritts D, and Rahnis M 2007 "Estimating Volume, Nutrient Content, and Rates of Stream Bank Erosion of Legacy Sediment in the Piedmont and Valley and Ridge Physiographic Provinces, Southeastern and Central PA." Pennsylvania Department of Environmental Protection, 40 pp.

Walter RC, and Merritts DJ. 2008 "Natural Streams and the Legacy of Water-Powered Mills." Science 319: 299-304. [PubMed: 18202284]

Winchell M, Srinivasan R, Di Luzio M, and Arnold JG. 2013 “ArcSWAT Interface for SWAT2012: User's Guide." Texas AgriLife Research and USDA Agricultural Research Service, 464 pp.

Yang CT 2006 Erosion and Sedimentation Manual. Denver, CO: U.S. Department of the Interior, Bureau of Reclamation. 


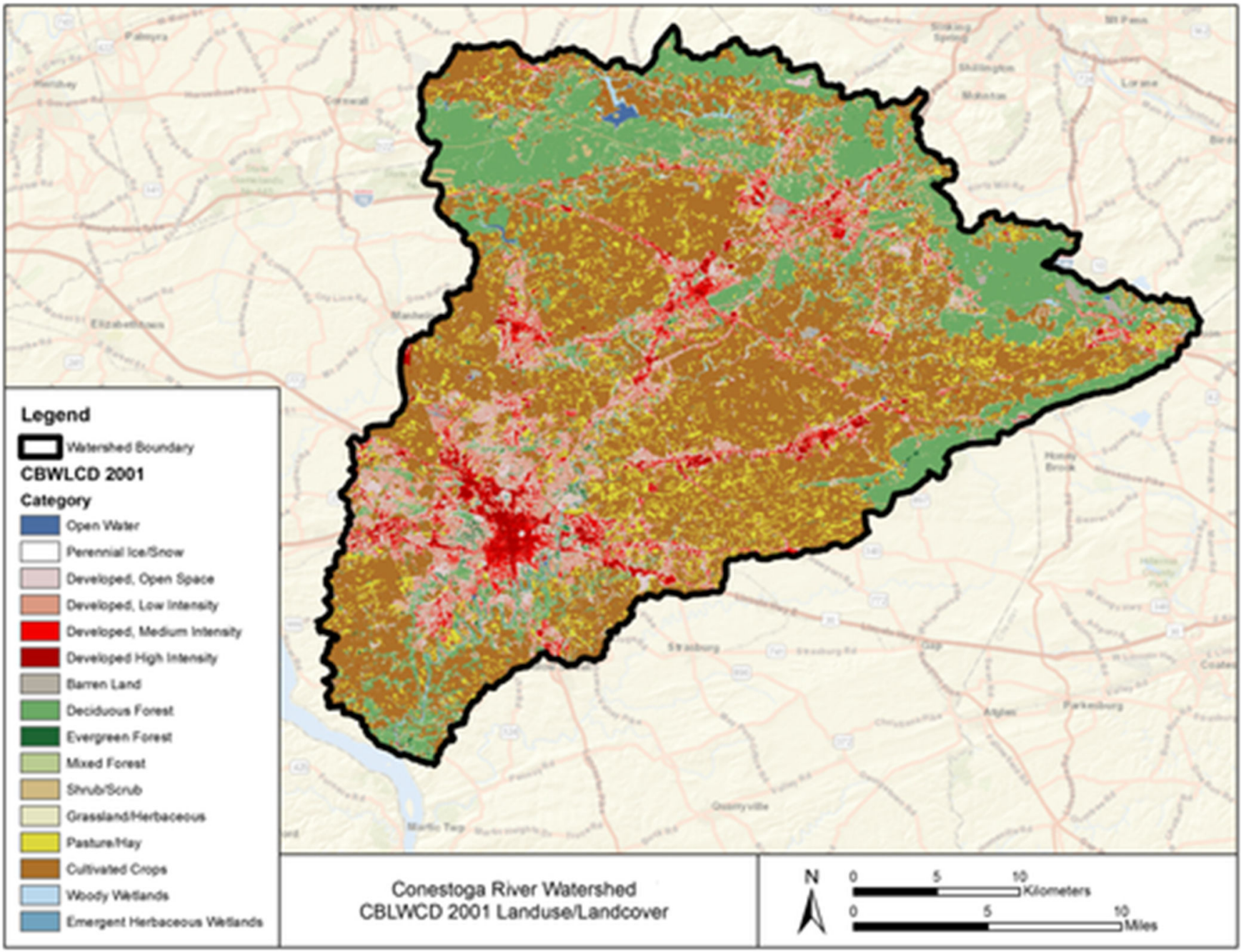

Figure 1.

Landuse in the Conestoga River watershed model. 


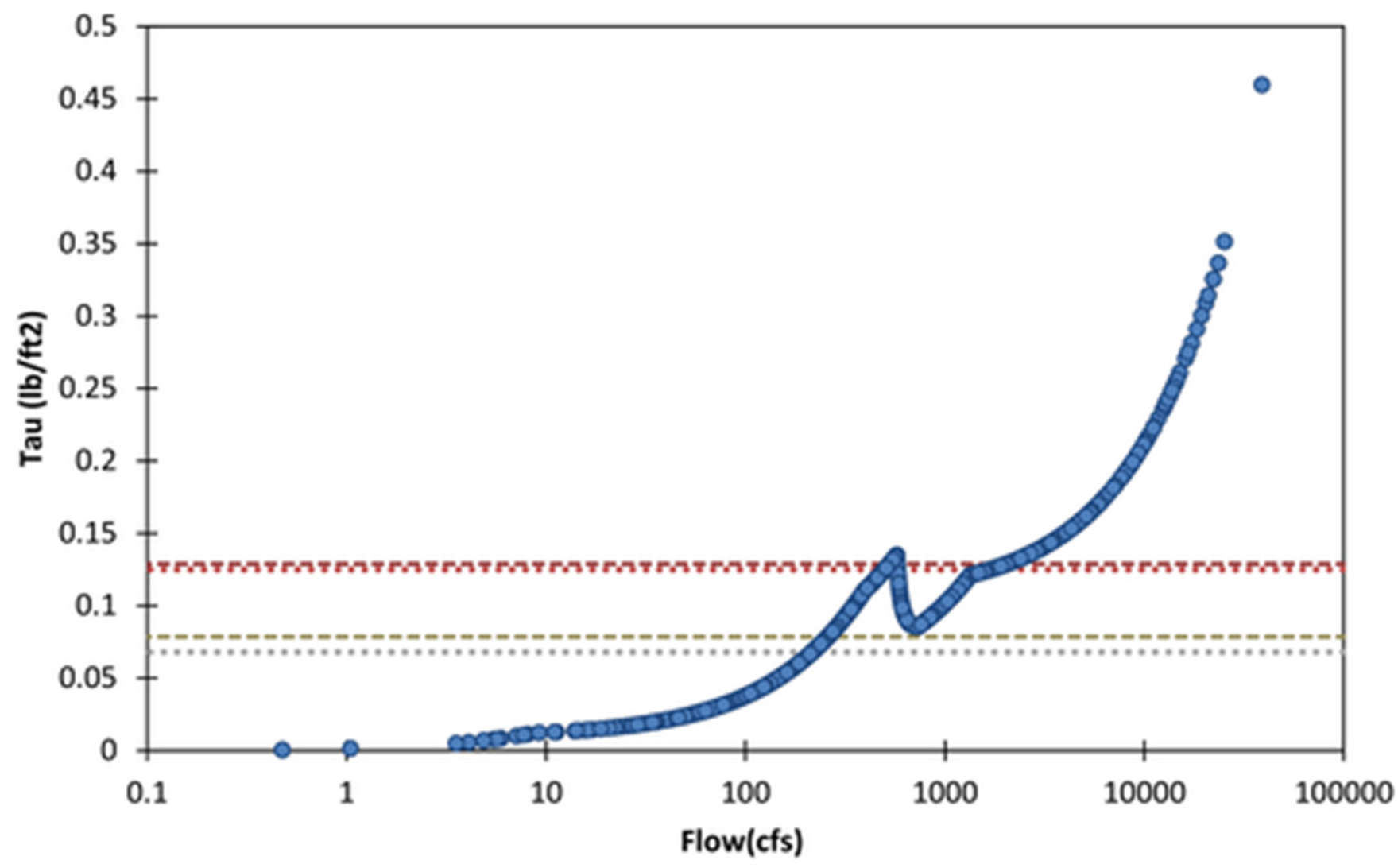

Figure 2.

Distribution of simulated shear stress against streamflow for a reach near the mouth of the Conestoga River (the 15th, 20th, 85th, and 90th percentile shear stresses are shown using dotted lines). 

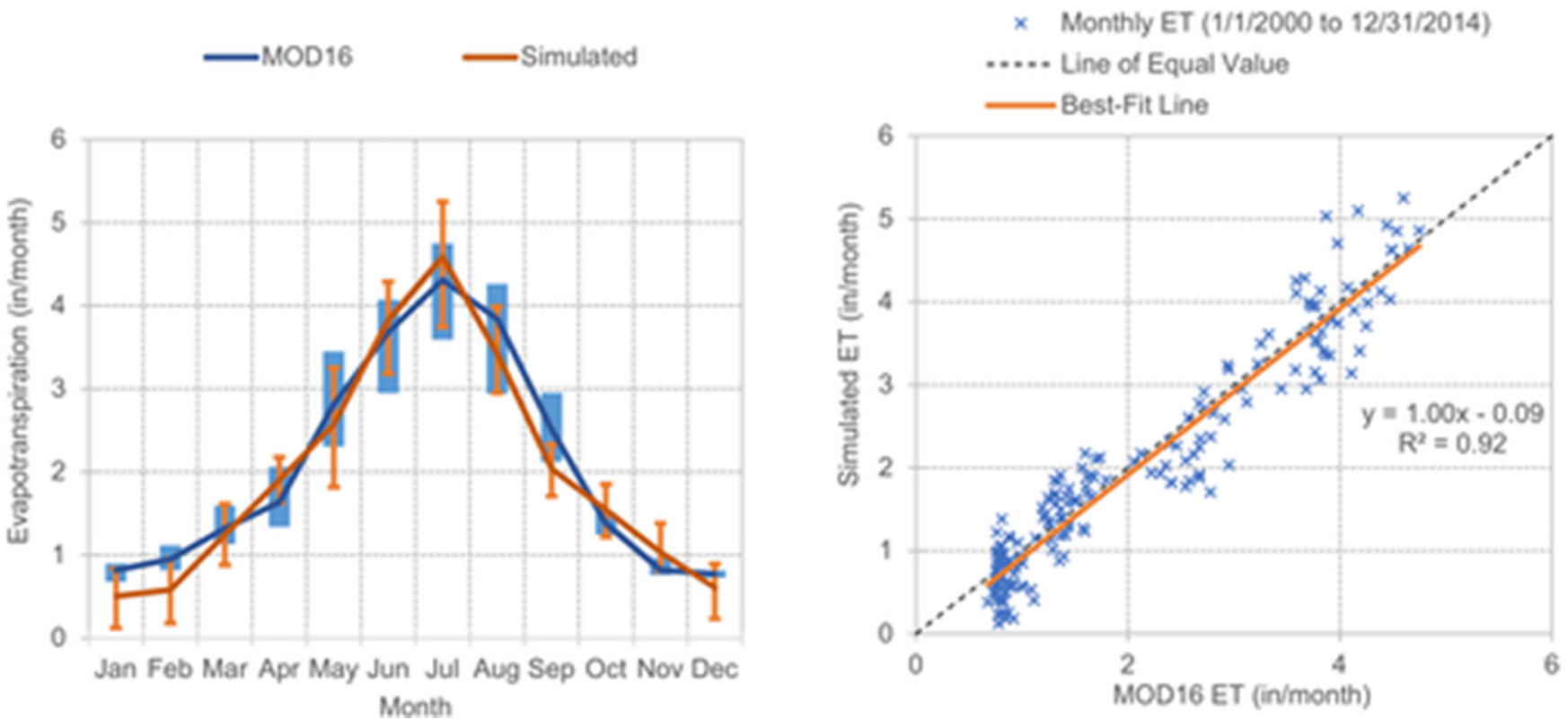

Figure 3.

Comparison of SWAT simulated evapotranspiration against MOD16 estimates 
$\times$ Daily Flow (10/1/2004 to 9/30/2014)

........ Line of Equal Value

Best-Fit Line

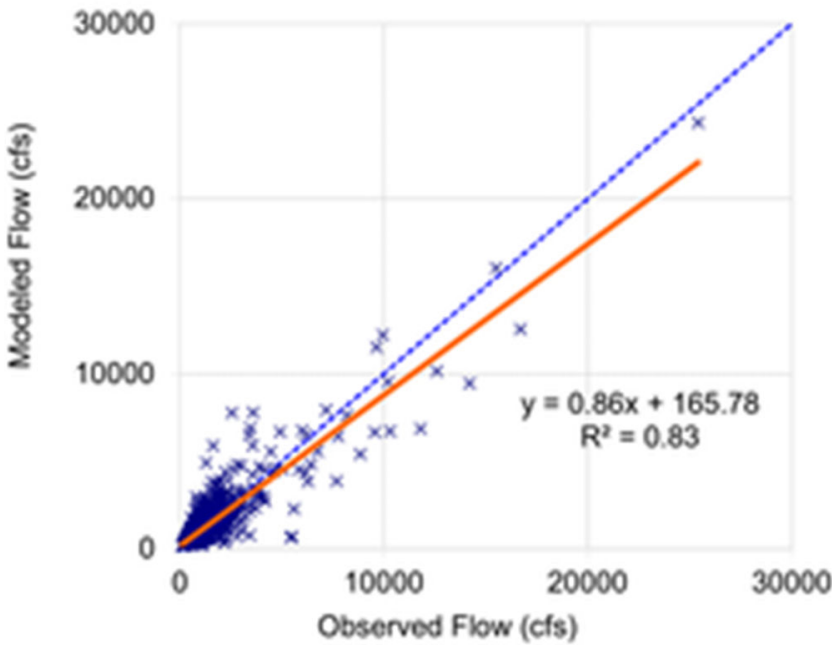

$\times$ Daily Flow (10/1/1994 to 9/30/2004 )

........ Line of Equal Value

-Best-Fit Line

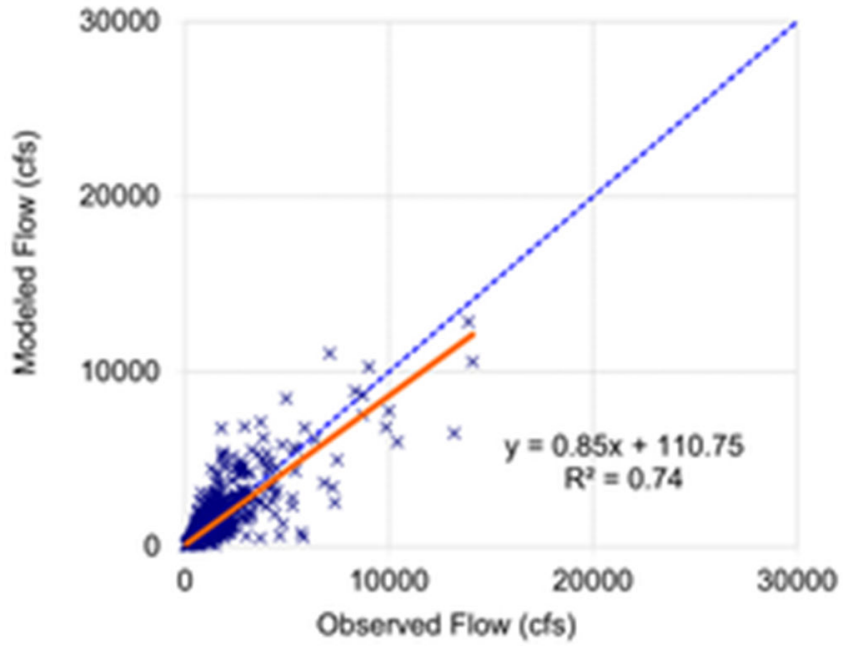

Figure 4.

Scatter plot of simulated against observed daily streamflow at the United States Geological Survey (USGS) gage at Conestoga for the calibration (left) and validation (right) periods. 
$\times$ Monthly Sediment Load (10/1/2004 to 9/30/2012)

-..- Line of Equal Value

Best-Fit Line

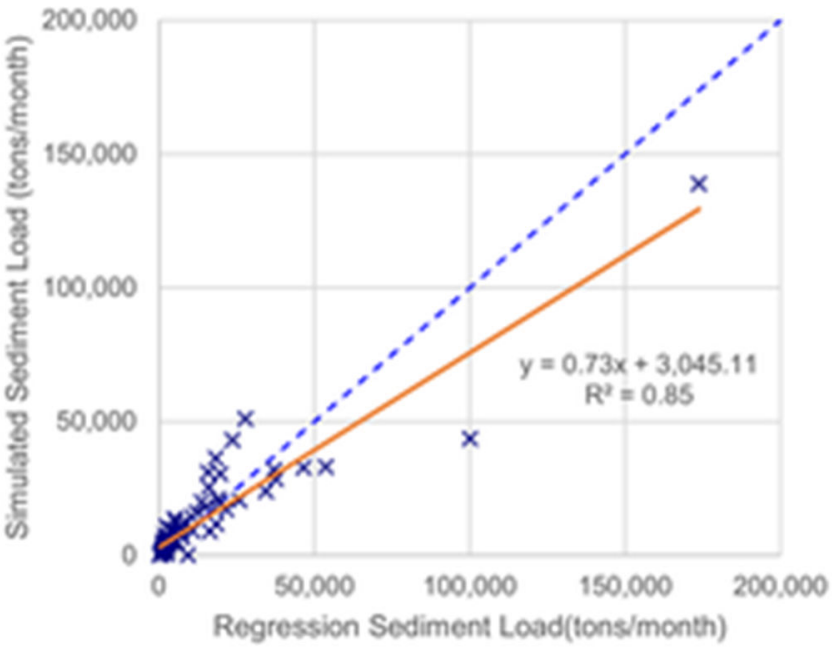

$\times$ Monthly Sodiment Load (10/1/1994 to 9/30/2004)

- - - Line of Equal Value -Best-Fit Line

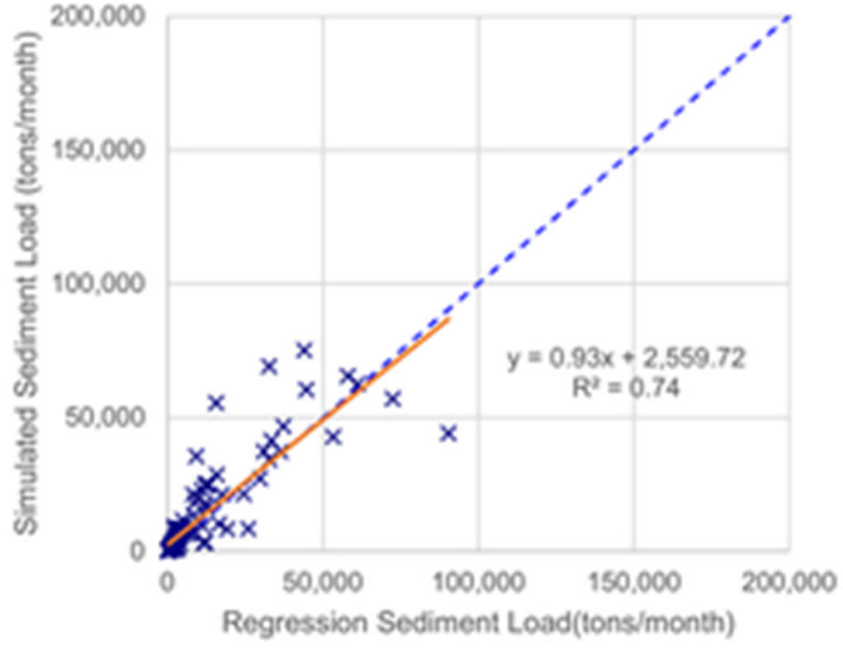

Figure 5.

Scatter plot of simulated against regression monthly sediment loads at the USGS gage at Conestoga for the calibration (left) and validation (right) periods. 


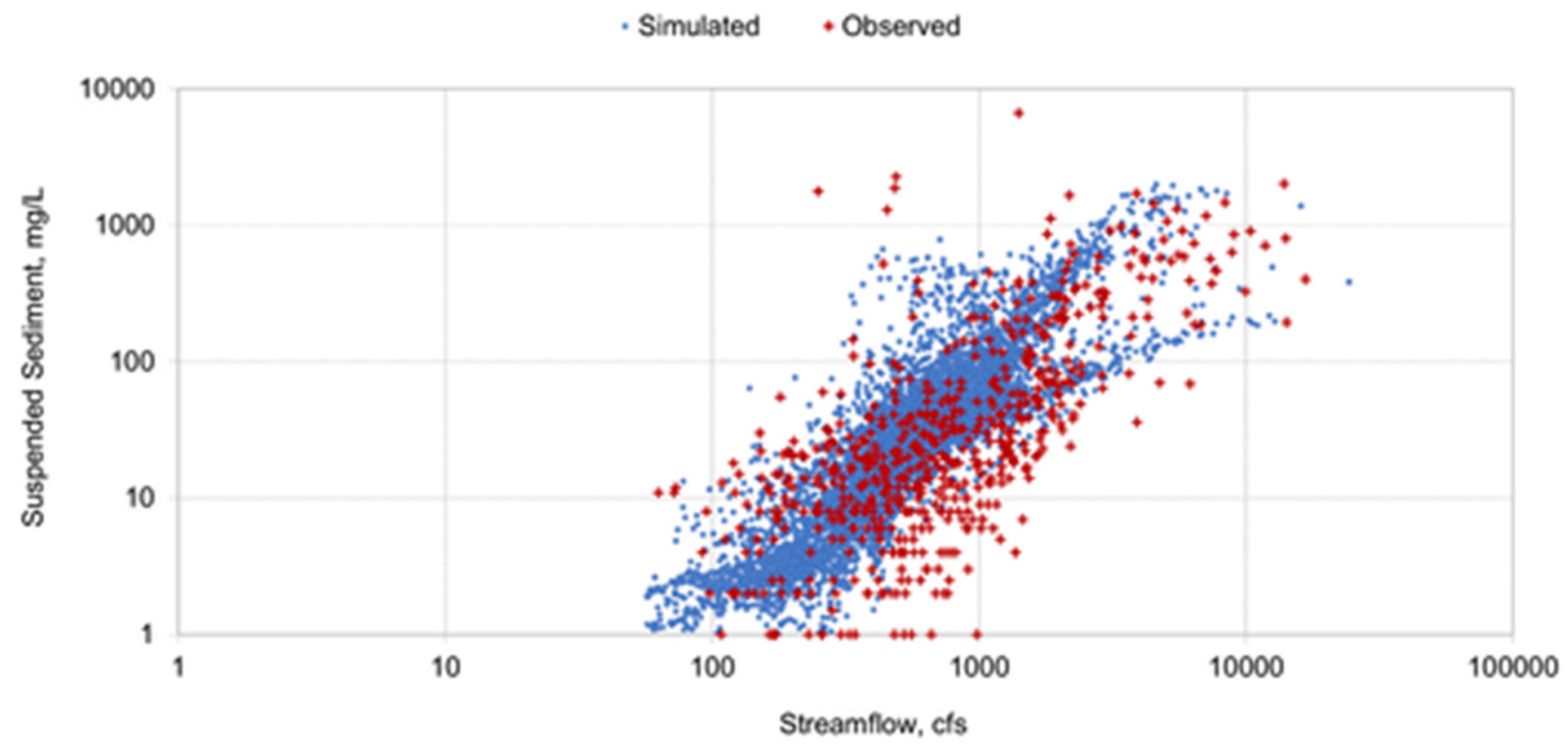

Figure 6.

Simulated and observed sediment concentration against streamflow at the USGS gage at Conestoga. 


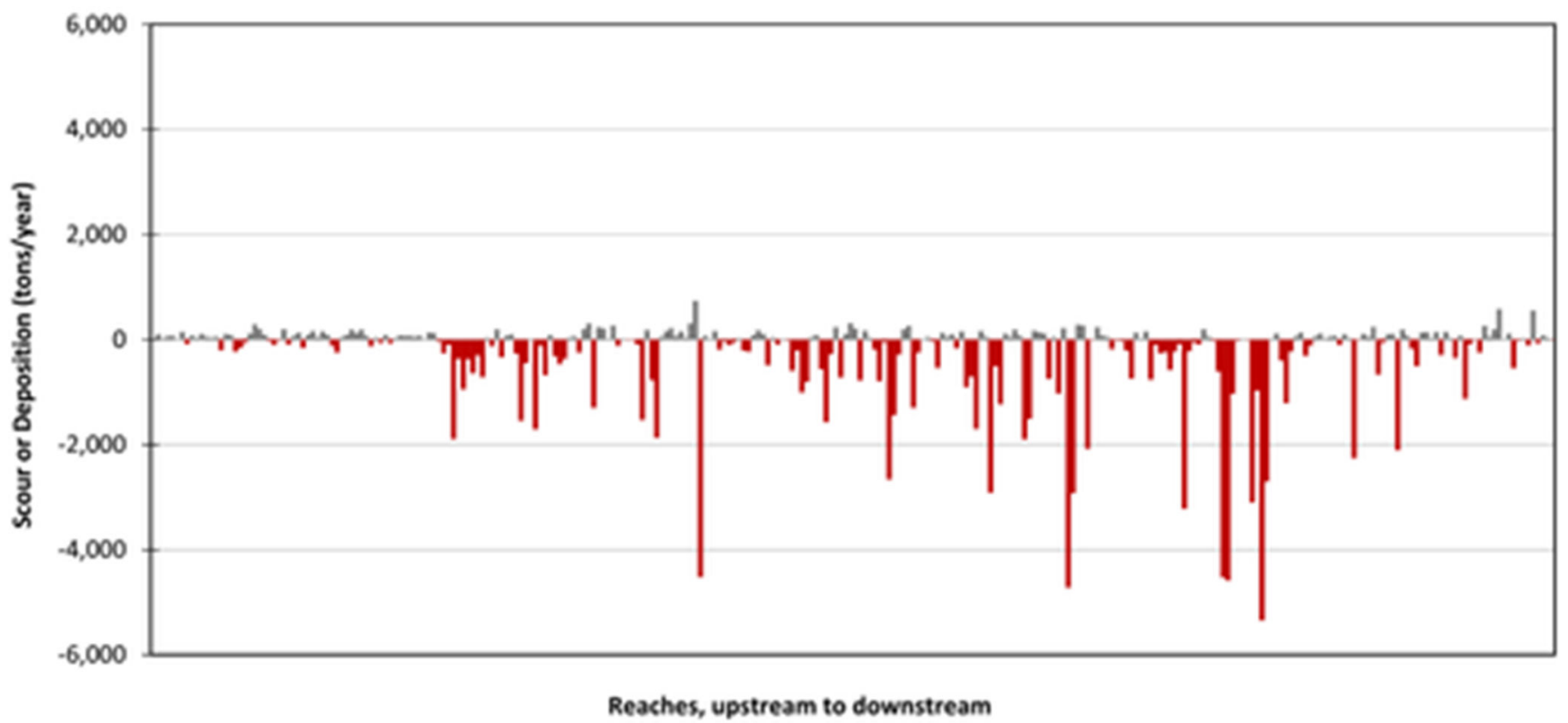

Figure 7.

Net scour and deposition simulated by the model on a reach by reach basis (red and gray represent scour and deposition, respectively). 


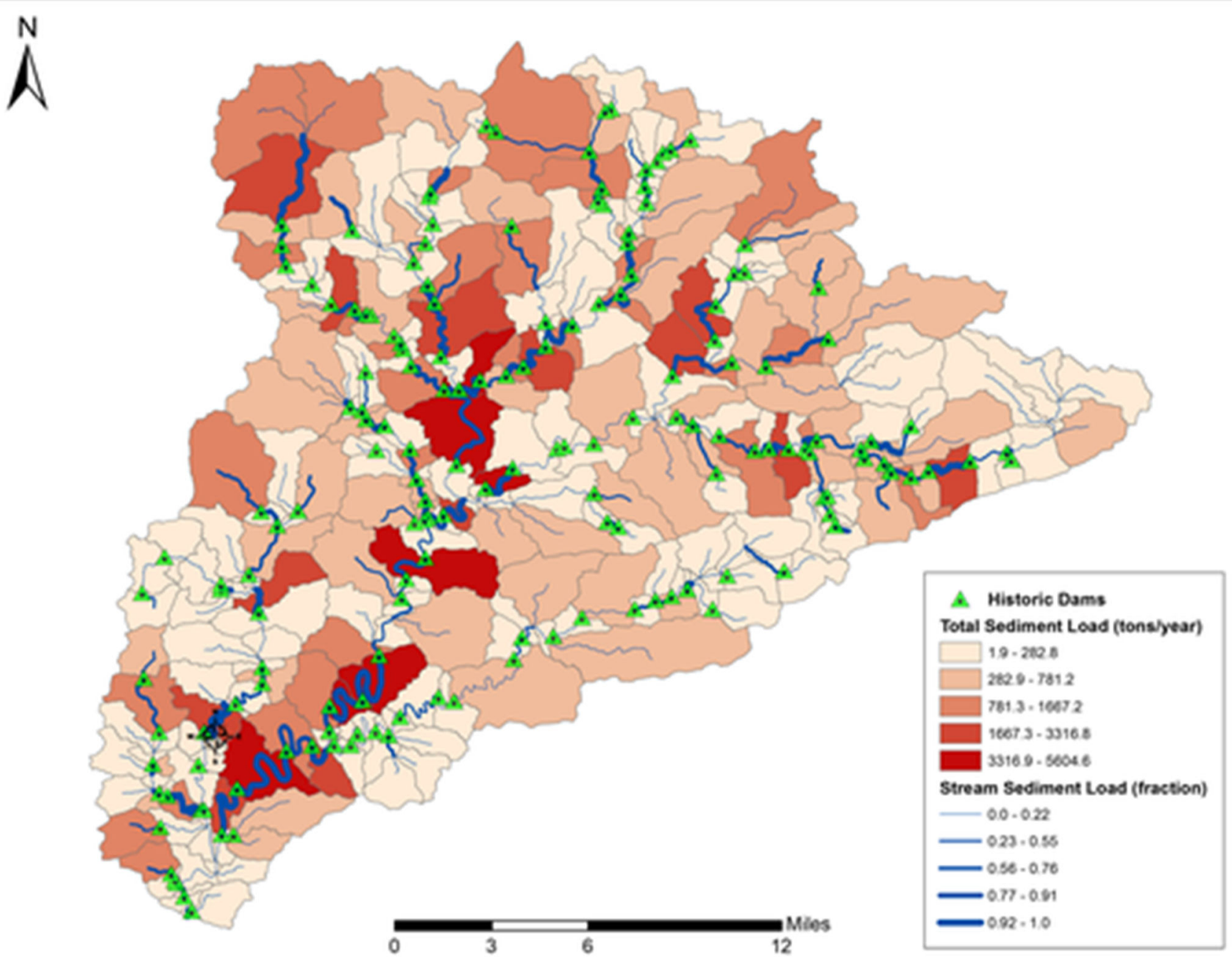

Figure 8.

Total sediment load and fraction from stream sources simulated by the model. 
Table 1.

Crop management practices in the Soil and Water Assessment Tool (SWAT) model

\begin{tabular}{|lll|}
\hline Crop name & Date or fraction of heat units & Operation (s) \\
\hline Grain corn & May-10 & Tillage \\
& May-15 & Planting, fertilizer application (20-60-0) \\
& Jun-20 & Fertilizer application (140-0-0) \\
Oct-31 & Harvest and kill \\
Silage corn & May-10 & Tillage \\
& May-15 & Planting, fertilizer application (22-125-0) \\
Jun-20 & Fertilizer application (157-0-0) \\
Soybean & May-25 & Harvest and kill \\
& May-31 & Tillage \\
Oct-31 & Planting, fertilizer application (0-50-0) \\
Generic Agricultural Row crop & 0.15 & Harvest and kill \\
& 0.01 & Tillage, planting \\
& 1.2 & Auto fertilization begin (161-0-0) \\
Hay & 0.15 & Harvest and kill \\
& 0.6 & Planting \\
& 0.85 & Harvest, fertilizer application (48-0-0) \\
1.2 & Harvest, fertilizer application (48-60-0) \\
& & Harvest, fertilizer application (48-0-0) \\
\hline
\end{tabular}


Table 2.

Parameters and sources for the development of Functional Tables

\begin{tabular}{|lll|}
\hline Parameter & Description & Source \\
\hline$Y_{\mathrm{m}}$ & Mean flow depth & Bieger et al. (2015) \\
$W_{\mathrm{m}}$ & Mean flow width & Bieger et al. (2015) \\
$L$ & Length of reach & Delineated SWAT model \\
$S$ & Longitudinal slope & Delineated SWAT model \\
$m_{\mathrm{c}}$ & Channel side slope & 1.0 (USEPA 2007) \\
$n$ & Manning's roughness coefficient & 0.03 (USEPA 2007) \\
$Y_{\mathrm{c}}$ & Bankfull depth & $1.25 Y_{\mathrm{m}}$ (USEPA 2007) \\
$Y_{t-1}$ & Floodplain split depth & $1.5 Y_{\mathrm{c}}$ (USEPA 2007) \\
$Y_{t-2}$ & Maximum floodplain depth & $62.5 Y_{\mathrm{m}}$ (USEPA 2007) \\
$W_{\mathrm{F}}$ & Floodplain width & $W_{\mathrm{m}}$ (USEPA 2007) \\
$m_{\mathrm{F}}$ & Floodplain side slope & 2.0 (USEPA 2007) \\
\hline
\end{tabular}


Table 3.

Performance targets for daily streamflow simulation

\begin{tabular}{|lllll|}
\hline Statistic & Very good & Good & Fair & Poor \\
\hline Error on volume (\%) & $\leq 10$ & $10-15$ & $15-25$ & $>25$ \\
$R^{2}$ & $>0.8$ & $0.7-0.8$ & $0.6-0.7$ & $<0.6$ \\
NSE & $>0.8$ & $0.7-0.8$ & $0.6-0.7$ & $<0.6$ \\
\hline
\end{tabular}

Note: NSE, Nash-Sutcliffe efficiency. 
Table 4.

SWAT model parameters adjusted during hydrology calibration and final values

\begin{tabular}{|lll|}
\hline Parameter & Description & Value \\
\hline ESCO & Soil evaporation compensation factor & 0.7 \\
SURLAG & Surface runoff lag time & 1 \\
GW_DELAY & Groundwater delay (days) & 10,75 (varies by subbasin) \\
ALPHA_BF & Baseflow alpha factor & 0.95 \\
GWQMN & Threshold depth of water in the shallow aquifer required for return flow to occur $(\mathrm{mm})$ & 0 \\
REVAPMN & Threshold depth of water in the shallow aquifer required for revap to occur $(\mathrm{mm})$ & 0 \\
SFTMP & Snowfall temperature $\left(\mathrm{C}^{\circ}\right)$ & 0 \\
SMTMP & Snowmelt temperature $\left(\mathrm{C}^{\circ}\right)$ & 0 \\
SMFMX & Maximum melt rate for snow during the year & 3 \\
SMFMN & Minimum melt rate for snow during the year & 1 \\
CH_N1 & Manning's $n$ value for tributary channel & 0.3 \\
CH_N2 & Manning's $n$ value for main channel & 0.03 \\
CH_K1 & Effective hydraulic conductivity in tributary channel alluvium $(\mathrm{mm} / \mathrm{h})$ & $0-300$ (varies by subbasin) \\
\hline
\end{tabular}


Table 5.

Hydrologic Simulation Program FORTRAN model parameters adjusted during sediment calibration and final values

\begin{tabular}{|lll|}
\hline Parameter & Description & Value \\
\hline$M$ & Erodibility coefficient & $0.001-3$ (varies by reach) \\
KSAND & Coefficient in sandload power function formula & $0.01-0.7$ (varies by reach) \\
EXPSAND & Exponent in sandload power function formula & 2 \\
\hline
\end{tabular}


Table 6.

Performance targets for suspended sediment simulation

\begin{tabular}{|lllll|}
\hline Statistic & Very good & Good & Fair & Poor \\
\hline Error on mean concentration $(\%)$ & $\varsigma 20$ & $20-30$ & $30-45$ & $>45$ \\
Error on mean monthly load $(\%)$ & $<15$ & $15-30$ & $30-55$ & $>55$ \\
Monthly NSE & $>0.75$ & $0.65-0.75$ & $0.5-0.65$ & $<0.5$ \\
\hline
\end{tabular}

少

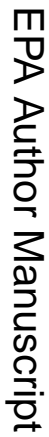


Table 7.

Model performances for monthly streamflow and sediment loads

\begin{tabular}{|lllll|}
\hline Statistic & \multicolumn{2}{l}{ Calibration period } & \multicolumn{2}{l|}{ Validation period } \\
& Streamflow & Suspended sediment & Streamflow & Suspended sediment \\
\hline NSE & 0.93 & 0.83 & 0.90 & 0.68 \\
RSR & 0.27 & 0.41 & 0.31 & 0.57 \\
PBIAS (\%) & -8.0 & -3.1 & -1.3 & -21.0 \\
\hline
\end{tabular}

Note:

- RSR, RMSE-observations standard deviation ratio; PBIAS, Percent Bias. 